[Transaction ]

\title{
The Influences of Perceived Risk on Attributes of Smart Clothing -Comparison among Korea, Spain, and U.S.-
}

\author{
Eunju Ko $\cdot$ Shintaro Okazaki* $\cdot$ Chang Han Lee ${ }^{\dagger} \cdot$ Hye Lim Yun \\ Dept. of Clothing \& Textiles, Yonsei University \\ *College of Economics \& Business Administration, Autonomous University of Madrid \\ Received March 26, 2009; Revised (May 13, 2009; June 2, 2009); Accepted June 5, 2009
}

\author{
지각된 위험이 스마트 의류 속성에 미치는 영향 연구 \\ -한국, 스페인, 미국 비교 연구- \\ 고은주 · Shintaro Okazaki* · 이창한 ${ }^{\dagger} \cdot$ 윤혜림 \\ 연세대학교 의류환경학과, *College of Economics \& Business Administration, Autonomous University of Madrid \\ 접수일(2009년 3월 26일), 수정일(1차 : 2009년 5월 13일, 완료일 : 2009년 6월 2일), 게재확정일(2009년 6월 5일)
}

\begin{abstract}
Smart clothing represents the future of both the textile/clothing industry and electronic industry and has an effort to make electronic devices a genuine part of our daily life. The researches about technologies innovation and application of smart clothing can be found in previous studies. But consumer researches about perception or attitude toward smart clothing can be hardly found. Therefore, we proposed a conceptual framework that explores the impact of perceived risks on perceived attributes to adopt smart clothing. In addition, we compared differences of this framework among three counties - Korea, U.S. and Spain. Based on the literature review and hypotheses development, a research model was constructed. After data analysis using Amos 7.0, the results can be concluded as following: First, the influences of psychological risk among Korea, U.S. and Spain are same. Psychological risk has negative effect on relative advantage and complexity, but has positive effect on trialability. Second, loss risk was found to have nothing to do with relative advantage. But it negatively influences complexity for Korean consumers and positively influences trialability for both Korean and American consumers. Third, the influences of performance risk for different consumers are different. At last, based on our discussion, some implications were also concluded.
\end{abstract}

Key words: Perceived risk, Perceived product attributes, Smart clothing; 지각된 위험, 지각된 제품 속성, 스마트 의류

\section{Introduction}

Smart clothing is designed to sense user requirements and environment contexts, and provide appropriate service at the right time and place accordingly with minimum effort required from the users and

Corresponding author

E-mail: fashion@yonsei.ac.kr operator (Marzano, 2000). It represents the future of both the textile/clothing industry and electronic industry and has an effort to make electronic devices a genuine part of our daily life by embedding entire systems into clothing and accessories. The impact of smart clothing will be great in the near future.

The idea of attaching small systems to garments first occurred in the late 1970s in the wearable com- 
puting field. Due to the advances in miniaturization, comprising a backpack-based, tetherless computer system together with wireless communications, has been transformed from an awkward and cumbersome burden into a completely unobtrusive internet-connected multimedia computer built within an ordinary clothing (Mann, 1997). However, the concept of smart clothing became widespread in a very short period of time. It draws great attention from many organizations in different fields. A number of research studies have been carried out by many academic institutes, e.g. MIT Media Lab, Royal College of Art, University of Bristol, Central Saint Martins College of Art \& Design, Brunel University and Tampere University of Technology. Governmental organization initiatives, particularly in the military field, such as NASA in the USA and Ministry of Defense in the UK, are considered as the main reasons for the fast development of intelligent textiles. Moreover, many high-tech companies conduct their own research or carry out collaborative work with academic institutes or sponsor external laboratories and/or design consultancy e.g. Starlab, and IDEO. Significantly, most of these organizations are multinational companies within the electronics industry, e.g. Nokia, Philips, Ericsson, Motorola, Pioneer Corporation and Infineon Technologies AG (Ariyatum \& Holland, 2003). Therefore, it can be deduced that the leading companies perceive smart clothing as the next generation of electronic devices, and the smart clothing is the next emerging market. Textile \& Fashion Korea (2007) predicted that smart wear market would be expanded to the areas of military, medical care, business, and leisure industry. The world market size is expected to reach $\$ 7$ billion in 2014, which is almost thirty five times increased in 2008.

The researches about technology innovation and application of smart clothing can be found in previous studies. But consumer researches about perception or attitude toward smart clothing can be hardly found. In consumers' decision making, such as in product perception, the concept of risk is often critical (Cox, 1967). Specially, innovative products involve more perceived risk than other traditional products. The purpose of this study is to find out how perceived risk can influence consumers' perceived attributes for smart clothing. Therefore, we proposed a conceptual framework that explores the impact of perceived risks on perceived attributes to adopt smart clothing. In addition, it is crucial to understand how the consumers in each country see their innovation options, understand how they make innovation trade off decision, and understand the different needs that drive their purchases. Thus, we compared differences of this framework among three counties - Korea, U.S. and Spain. The findings of this study will provide the guideline for global companies which are doing or going to do smart clothing business.

\section{Literature Review}

\section{Perceived Attributes of Smart Clothing}

Product attributes which is defined by American Marketing Association are the characteristics by which product are identified and differentiated. Product attributes usually comprise features, functions, benefits and uses. Another definition given by Hamilton (2007) is that a product attribute provides an important detail of retail product that facilities comparison and classification with similar product. A few examples of product attributes are: size, color, material, weight, display size, battery life, power rating, age range, processor speed, etc. Lancaster (1966) emphasized the need to explain and predict consumer demand based on the characteristics or attributes embodied within goods or services. Products themselves are not the objects of desire, but have attributes associated with them that are important to consumers.

But smart clothing can not be just seen as a product, but also an innovation. Rogers (1995) defined innovation as "an idea, practice, or object that is perceived as new by an individual or other unit of adoption". The attributes of the innovation themselves have tended to receive rather less attention than the personal characteristics of innovators (Black et al., 2001). According to Littrell and Miller's study (2001), familiarity with overall garment features (including relative advantage, compatibility with existing value system, and observability) and compatibility with existing wardrobe were significant to predict purchase intention of India-inspired 
garments. Sung and Slocum (2004) investigated the intention to adopt UV protective clothing among U.S. golfers, and found that trialability, compatibility, and relative advantage in order were significantly and positively associated with the intention to adoption. When Sung and Jeon (2005) examined the adoptability of UV protective golf wear among Korean consumers, compatibility, trialability, and relative advantage in order were significant predictors for purchase intention. Based on all the researches, smart clothing can be described by three attributes that influence the rate of adoption of the innovation, such as relative advantages, complexity and trialability.

First, relative advantage is concerned with the degree to which an innovation is perceived by potential adopters as being better than three idea, product or service it supersedes (Rogers, 1995). The construct of relative advantage is highly domain specific, although dimensions that are found to have some generality include reduced costs and greater convenience (Black et al., 2001). For this study, relative advantages include economic benefit, social advantage (good image), or usefulness (functionality, comfortableness). Second, complexity of an innovation is the degree to which it is perceived as relatively difficult to understand and use by members of a social system (Rogers, 1983). Littrell and Miller (2001) argued that complexity of clothing would be high when additional learning of garment construction or care instructions were required due to lack of familiarity with the garment. Smart clothes carry various digital devices whose diverse functions increase the complexity. Third, in Rogers (1995) research, trialability refers to the degree to which an innovation is perceived as being trialable on a limited basis prior to any decision to adopt. If potential adopters have a chance to see demonstrations or to try on before actual adoption, it would be helpful to reduce uncertainty about smart clothing.

\section{Perceived Risk}

Perceived risk was first defined by Bauer (1960) as a term of the uncertainty and consequences associated with a consumer's action (Shin \& Park, 2006). Perceived risk, therefore, is a function of the unex- pected results of adoption and an outcome that deviates from expectation (Forsythe \& Shi, 2003; Hirunyawipada \& Paswan, 2006).

Perceived risk has been studied extensively in consumer behavior literature (e.g., Chung \& Oh, 2001; Conchar et al., 2004; Huh, 2004; Kim \& Shin, 2000). A number of conceptualizations have been offered, but generally are based on the premise that consumer is sensitive to both the probability and extent of potential loss associated with a purchase (Taylor, 1974). When consumers venture into the adoption of new products, they face a dilemma between desirable and undesirable consequences of the adoption and hence face a risk decision (Mitchell et al., 1999; Zinkhan \& Karande, 1991). Although some researches have mentioned that product attributes could influence perceived risk (e.g. Ostund, 1974), perceived risk would also affect consumer's perception of attributes of an innovation (Ko et al., 2008).

Ziamou (2002) found that consumers find more uncertainty in innovations that do not provide consumer with new functionality, but rather change the interface of already existing functionality in technological markets. In other words, not all the dimensions of perceived risk may have influences on innovative products. In this paper, most of the consumers have never tried smart clothing before and barely had much knowledge about smart clothing. Social risk and economy risk were not considered as much as other risks. Thus, only three dimensions were used to measure perceived risk, which are psychological risk, time loss risk and performance risk.

Psychological risk refers to the anxiety or disappointment caused by post-purchase results (Chen \& He, 2003). It refers to how the consumer perceives himself after making a purchase decision. Time risk refers to concerns in loss of money or time invested to buy the product. One could argue that in the busy society of today, people would not spend so much time on learning how to use any new technology. Mieres et al. (2006) stated that psychological risk and time loss risk negatively influence consumers' store brand proneness. Uncertainty of smart clothing adoption would hinder from viewing the positive sides of attributes of new products. Thus, psychological risk 
and time loss risk will be negatively influence consumer's perceived attributes for smart clothing.

H1: Psychological risk will be negatively associated with (a) relative advantage, (b) complexity and (c) trialability.

$\mathrm{H} 2$ : Time loss risk will be negatively associated with (a) relative advantage, (b) complexity and (c) trialability.

Performance risk refers to concerns about failure to product function as expected. Consumers' evaluation of performance risk is based on their knowledge and cognitive abilities in a certain product domain (Ram \& Sheth, 1989). However, these concerns might be mitigated by consumers' expertise and interest in the highly innovative product domain (Mitchell \& Harris, 2005; Mowen \& Minor, 2001). The technologies which are used in smart clothing have already been used in our daily life and some other industries. Thus, consumers might already have high level of knowledge about the technologies of smart clothing. Therefore, performance risk will be result in positive affect on perceived attributes of smart clothing.

H3: Performance risk will be positively associated with (a) relative advantage, (b) complexity and (c) trialability.

\section{Methods}

\section{Research Design}

Based on the discussion so far, we developed the relationship between perceived risk and perceived attributes of smart clothing. Then a research model was constructed as shown in 〈Fig. 1>.

\section{Questionnaire Design}

A self-administered questionnaire was developed in English based on previous studies. Psychological risk, time loss risk and performance risk were separately measured by 2 items which mentioned by previous researches (Chen \& He, 2003; Robert \& Kjell, 1993; Sung \& Slocum, 2004). As innovative product, smart clothing attributes, such as relative advantage, complexity, and Trialability, were measured by Rogers' (1995) model. All the questions were measured using a five-point Likert-type scale ranging from "strongly disagree" (1) to "strongly agree" (5). Demographic information included nationality, age, sex, college major, monthly household income, and the monthly clothing expense. The questionnaire was translated into Spanish and English by using back-translation techniques.

\section{Sample and Data Collection}

To test our hypothesized model - capturing the relationships among global smart clothing market, the data were collected during fall semester of 2006 from university students in Korea, Spain and the United States who were relatively sensitive to innovative products than other age groups. A two-way language barrier complicated the comparison of respondents, and translations were discussed and modified so that the items on the questionnaires conveyed the same meaning.

A total of 705 final useful questionnaires were analyzed: 300 Korean, 94 Spanish, and 311 U.S. respon-

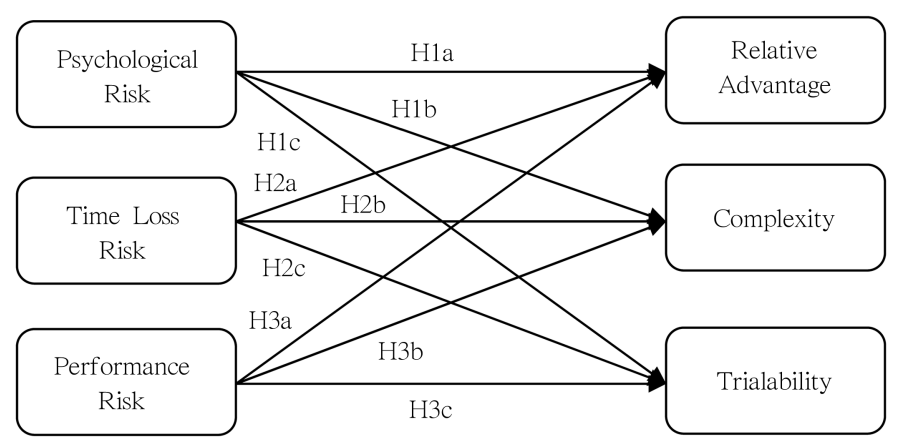

Fig. 1. Research model. 
Table 1. Demographic analysis

\begin{tabular}{|c|c|c|c|c|c|}
\hline Category & $\begin{array}{c}\text { Total } \\
(\mathrm{N}=705)\end{array}$ & $\begin{array}{c}\text { Korean } \\
(\mathrm{N}=300)\end{array}$ & $\begin{array}{l}\text { Spanish } \\
(\mathrm{N}=94)\end{array}$ & $\begin{array}{c}\text { U.S. } \\
(\mathrm{N}=311)\end{array}$ & $\chi^{2}$ \\
\hline $\begin{array}{l}\text { Gender } \\
\text { Male } \\
\text { Female }\end{array}$ & $\begin{array}{l}356(50.5 \%) \\
348(49.4 \%)\end{array}$ & $\begin{array}{l}181(60.3 \%) \\
119(39.7 \%)\end{array}$ & $\begin{array}{l}31(33.0 \%) \\
62(66.0 \%)\end{array}$ & $\begin{array}{l}144(46.3 \%) \\
167(53.7 \%)\end{array}$ & $24.760 * * *$ \\
\hline $\begin{array}{c}\text { Product Awareness } \\
\text { Yes } \\
\text { No }\end{array}$ & $\begin{array}{l}323(48.5 \%) \\
382(54.2 \%)\end{array}$ & $\begin{array}{l}178(59.3 \%) \\
122(40.7 \%)\end{array}$ & $\begin{array}{l}41(43.6 \%) \\
53(56.4 \%)\end{array}$ & $\begin{array}{l}104(33.4 \%) \\
207(66.6 \%)\end{array}$ & $41.451 * *$ \\
\hline $\begin{array}{c}\text { Purchased Experience } \\
\text { Yes } \\
\text { No }\end{array}$ & $\begin{array}{r}16(2.3 \%) \\
689(97.7 \%)\end{array}$ & $\begin{array}{r}9(3.0 \%) \\
291(97.0 \%)\end{array}$ & $\begin{array}{r}1(1.1 \%) \\
93(98.9 \%)\end{array}$ & $\begin{array}{r}6(1.9 \%) \\
305(98.1 \%)\end{array}$ & 1.500 \\
\hline Category & Total & Korean & Spanish & U.S. & F-tests \\
\hline Age & $20.98(2.12)$ & $21.33(2.21)$ & $23.12(2.55)$ & $20.00(1.03)$ & $111.42 * * *$ \\
\hline Consumption for Apparel & $2.55(1.12)$ & $2.61(1.10)$ & $2.15(.91)$ & $2.62(1.18)$ & $6.99 * *$ \\
\hline Family Income & $4.08(1.70)$ & $3.23(1.43)$ & $3.08(1.52)$ & $5.21(1.27)$ & $173.81 * * *$ \\
\hline Product Attitude & $2.22(.73)$ & $2.96(.56)$ & $1.90(.77)$ & $3.36(.59)$ & $12.85^{* * *} *$ \\
\hline Purchase Intention & $2.57(.80)$ & $2.64(.65)$ & $2.46(.85)$ & $2.76(.74)$ & $11.404 * * *$ \\
\hline
\end{tabular}

dents. As demonstrated in 〈Table 1〉, about 50.5 percent of the respondents were male with the mean age of 20.98 years old (ranged from 18 to 30 ). About $48.5 \%$ reported that they were aware of smart clothing, and only 16 respondents purchased it. Significant differences among Korean, Spanish, and U.S. respondents were found in age, gender, family income, and product awareness. Americans were the youngest and earning the highest household income. Only $33.4 \%$ of Americans were aware of smart clothing, while $43.6 \%$ of Spanish and 59.3\% of Koreans were aware of it. However, American respondents presented the most positive attitudes toward smart clothing, but Spanish respondents presented the least positive attitudes.

\section{Results and Discussion}

\section{Confirmatory Factor Analysis}

A series of confirmatory factor analysis models were estimated using the data from the U.S., Korean and Spanish samples. The two-step approach to structural equation modeling suggested by Anderson and Gerbing (1988) was used in this study. Before estimating the paths to test the relationship among constructs, a confirmatory factor analysis for the six constructs and their indicators was conducted to assess con- struct, convergent and discriminate validity through Amos 7.0. <Table 2> indicates the results of the CFA for the measurement model and gives factor loadings and t-values.

$<$ Table 2> also indicates that every item has a significant t-value on its latent construct. For each country, the CFA model is acceptable because each GFI (for Korea, GFI=.965; for U.S., GFI=.950; for Spain, $\mathrm{GFI}=.907$ ) and AGFI (for Korea, AGFI=.930; for U.S., AGFI=.910; for Spain, AGFI=.830) value are acceptable. Cronbach's alpha was used for reliability test. Most of the value of Cronbach's alpha are higher than 0.6, therefore, reliability of the data from three countries was good enough to be further analyzed. In summary, the selected items make reliable and valid measures for the research constructs.

\section{Hypotheses Test}

To test the hypotheses, a structural equation model was estimated (Fig. 2), (Table 4). We estimated path coefficients using maximum likelihood (ML) estimation in the structural equation modeling method (Bollen, 1989). In testing the main effects from perceived risk to product attributes, we followed Anderson and Gerbing's (1988) method. The analysis was conducted for the three data sets from Korea, U.S. and Spain 
Table 2. Results of confirmatory factor analysis

\begin{tabular}{|c|c|c|c|c|c|c|c|c|c|c|}
\hline \multirow{2}{*}{ Item } & \multirow{2}{*}{ Scale } & \multicolumn{3}{|c|}{ Factor Loadings } & \multicolumn{3}{|c|}{ t-value } & \multicolumn{3}{|c|}{ Cronbach's alpha } \\
\hline & & Korea & U.S. & Spain & Korea & U.S. & Spain & Korea & U.S. & Spain \\
\hline \multirow{2}{*}{ Psychological Risk } & $\mathrm{R} 1$ & .681 & .824 & .803 & 9.38 & 12.25 & 4.84 & \multirow{2}{*}{.70} & \multirow{2}{*}{.75} & \multirow{2}{*}{.77} \\
\hline & $\mathrm{R} 2$ & .777 & .730 & .773 & Fix & Fix & Fix & & & \\
\hline \multirow{2}{*}{ Time Loss Risk } & R3 & .800 & .873 & .533 & 8.54 & 5.50 & 2.17 & \multirow{2}{*}{.69} & \multirow{2}{*}{.78} & \multirow{2}{*}{.69} \\
\hline & $\mathrm{R} 4$ & .893 & .723 & .600 & Fix & Fix & Fix & & & \\
\hline \multirow{2}{*}{ Performance Risk } & R5 & .748 & .654 & .723 & 6.49 & 3.36 & 2.42 & \multirow{2}{*}{.83} & \multirow{2}{*}{.84} & \multirow{2}{*}{.85} \\
\hline & R6 & .701 & .496 & .730 & Fix & Fix & Fix & & & \\
\hline \multirow{2}{*}{ Relative Advantage } & A1 & .787 & .613 & .895 & 5.10 & 8.21 & 2.00 & \multirow{2}{*}{.60} & \multirow{2}{*}{.67} & \multirow{2}{*}{.61} \\
\hline & $\mathrm{A} 2$ & .414 & .602 & .354 & Fix & Fix & Fix & & & \\
\hline \multirow{2}{*}{ Complexity } & A3 & .481 & .613 & .722 & 4.18 & 7.49 & 2.85 & \multirow{2}{*}{.62} & \multirow{2}{*}{.63} & \multirow{2}{*}{.60} \\
\hline & A4 & .553 & .495 & .492 & Fix & Fix & Fix & & & \\
\hline \multirow{2}{*}{ Trialability } & A5 & .919 & .571 & .769 & 3.20 & 2.22 & 2.24 & \multirow{2}{*}{.57} & \multirow{2}{*}{.58} & \multirow{2}{*}{.62} \\
\hline & A6 & .489 & .602 & .540 & Fix & Fix & Fix & & & \\
\hline \multicolumn{2}{|l|}{$\chi^{2}$} & 64.4 & 105.9 & 45.2 & & & & & & \\
\hline \multicolumn{2}{|l|}{$\mathrm{df}$} & 40 & 40 & 40 & & & & & & \\
\hline \multicolumn{2}{|l|}{ GFI } & .965 & .948 & .926 & & & & & & \\
\hline \multicolumn{2}{|l|}{ AGFI } & .930 & .898 & .856 & & & & & & \\
\hline \multicolumn{2}{|l|}{ RMR } & .046 & .050 & .083 & & & & & & \\
\hline RMSEA & & .047 & .073 & .037 & & & & & & \\
\hline
\end{tabular}

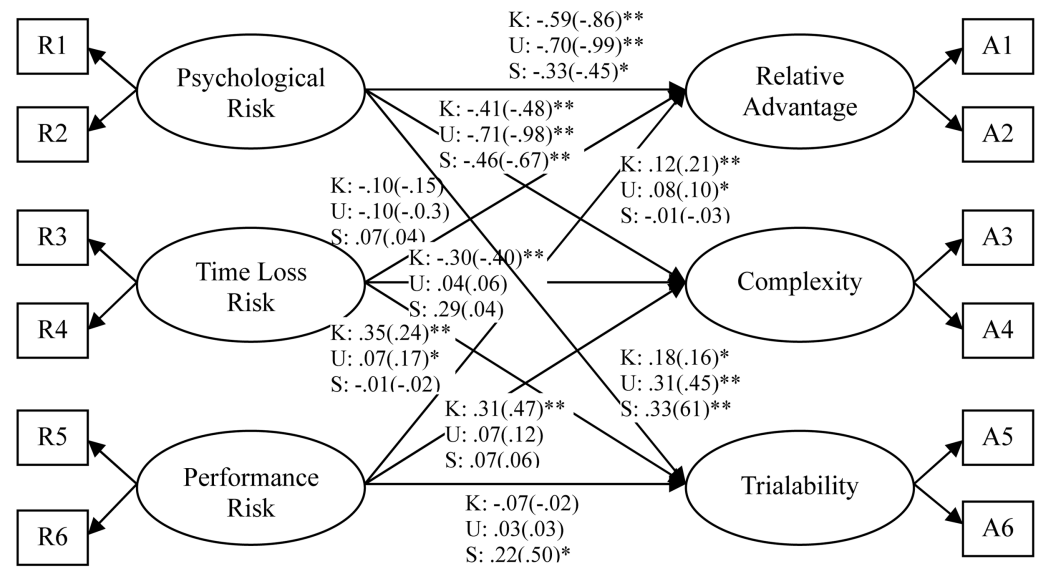

\section{K: Korea; U: U.S.; S: Spain}

R1: Hard to match with my other clothes; R2: Not fit my style; R3: pay extra to exchange the clothes; R4: Take more time for difficult and inconvenient to exchange; R5: Harmful electron wave to cause physical risk; R6: Does not guarantee physical safety; A1: Improve my image; A2: More functional and comfortable; A3: Difficult to understand how it works; A4: Difficult to explain its advantages; A5: If it is available in store, I will try; A6: If I use it, the advantages will be apparent to me.

$* p<.05, * * p<.01$

Fig. 2. Unstandardized and standardized estimation of hypothesis testing. 
Table 3. Correlation matrix

\begin{tabular}{|c|c|c|c|c|c|c|c|c|c|c|c|c|c|c|c|c|c|c|}
\hline \multirow{2}{*}{ Division } & \multicolumn{3}{|c|}{ Psychological } & \multicolumn{3}{|c|}{ Time Loss Risk } & \multicolumn{3}{|c|}{ Performance } & \multicolumn{3}{|c|}{ Advantage } & \multicolumn{3}{|c|}{ Complexity } & \multicolumn{3}{|c|}{ Trialability } \\
\hline & K & $\mathrm{U}$ & $S$ & K & $\mathrm{U}$ & $S$ & K & $\mathrm{U}$ & $S$ & K & $\mathrm{U}$ & $S$ & K & $\mathrm{U}$ & $S$ & K & $\mathrm{U}$ & $S$ \\
\hline Psychological & 1.00 & 1.00 & 1.00 & & & & & & & & & & & & & & & \\
\hline Time Loss & .18 & .26 & .26 & 1.00 & 1.00 & 1.00 & & & & & & & & & & & & \\
\hline Performance & .21 & .29 & .20 & .42 & .15 & .18 & 1.00 & 1.00 & 1.00 & & & & & & & & & \\
\hline Advantage & -.78 & -.92 & -.50 & -.22 & -.28 & -.10 & -.03 & -.16 & -.14 & 1.00 & 1.00 & 1.00 & & & & & & \\
\hline Complexity & -.43 & -.82 & -.29 & -.40 & -.21 & .15 & -.33 & -.16 & -.11 & .51 & 1.00 & .21 & 1.00 & 1.00 & 1.00 & & & \\
\hline Trialability & -.32 & .67 & .04 & -.30 & .40 & .04 & .20 & -.20 & .13 & .58 & -.72 & .01 & .21 & -1.1 & -.25 & 1.00 & 1.00 & 1.00 \\
\hline
\end{tabular}

Table 4. The result of structural equation modeling

\begin{tabular}{|c|c|c|c|c|c|c|c|}
\hline & \multirow{2}{*}{ Hypothetical Path } & \multicolumn{3}{|c|}{ Path Estimates } & \multicolumn{3}{|c|}{ t-value } \\
\hline & & Korea & U.S. & Spain & Korea & U.S. & Spain \\
\hline \multirow{3}{*}{$\mathrm{H} 1$} & (a) Psychological Risk Relative Advantage & $-.59 * *$ & $-.70 * *$ & $-.33^{*}$ & -5.16 & -9.17 & -2.01 \\
\hline & (b) Psychological Risk Complexity & $-.41 * *$ & $-.71 * *$ & $-.46 * *$ & -4.37 & -8.94 & -3.17 \\
\hline & (c) Psychological Risk Trialability & $.18^{*}$ & $.31 * *$ & $.33 *$ & 2.00 & 4.43 & 2.17 \\
\hline \multirow{3}{*}{$\mathrm{H} 2$} & (a) Time Loss Risk Relative Advantage & -.10 & -.01 & .07 & -1.76 & -.62 & .93 \\
\hline & (b) Time Loss Risk Complexity & $-.30 * *$ & .04 & .29 & -3.33 & .13 & 1.73 \\
\hline & (c) Time Loss Risk Trialability & $.35^{* *}$ & $.07 *$ & -.01 & 3.04 & 2.17 & -.06 \\
\hline \multirow{3}{*}{ H3 } & (a) Performance Risk Relative Advantage & $.12 *$ & $.08 *$ & -.01 & 2.77 & 2.47 & -.28 \\
\hline & (b) Performance Risk Complexity & $.31 * *$ & .07 & .07 & 4.22 & 1.83 & .78 \\
\hline & (c) Performance Risk Trialability & -.07 & .03 & $.22 *$ & -1.02 & .99 & 2.04 \\
\hline
\end{tabular}

$* p<.05, * * p<.01$

which produced the following fit indexes. For Korean respondents, Chi-square $=206.5(\mathrm{df}=56$, p-value $=.000)$, $\mathrm{GFI}=.91, \mathrm{AGFI}=.85$; for U.S. respondents, Chi-square $=183.4(\mathrm{df}=56$, p-value=.000), GFI=.92, AGFI=.86; and for Spanish respondents, Chi-square $=92.2(\mathrm{df}=56$, $\mathrm{p}$-value=.000), GFI=.90, AGFI=.85. As Lattin et al. (2003) mentioned that one rule for an acceptable fit of confirmatory factor analysis, GFI should exceed 0.90 and AGFI should exceed 0.85, our research model fits well into data structures collected from three countries. The correlation matrices for the three countries are presented in $\langle$ Table 3$\rangle$.

\section{1) Korean Respondents}

For Korean respondents, psychological risk was found to negatively influence relative advantage $(\beta=-$ $.59, \mathrm{t}=-5.16)$, complexity $(\beta=-.41, \mathrm{t}=-4.37)$, but positively influence trialability $(\beta=.18, \mathrm{t}=2.00)$. Additionally, time loss risk was found to negatively influence complexity $(\beta=-.30, t=-3.33)$ but positively influence trialability $(\beta=.35, \mathrm{t}=3.04)$. The relationship between time loss risk and relative advantage was not significant. Finally, Performance risk was found to have positive influence on relative advantage $(\beta=.12, \mathrm{t}=2.77)$ and complexity $(\beta=.31, \mathrm{t}=4.22)$.

\section{2) U.S. Respondents}

For U.S. respondents, the results showed that psychological risk have negative relationship with relative advantage $(\beta=-.70, t=-9.17)$ and complexity $(\beta=-.71$, $\mathrm{t}=-8.94)$. But the relationship between psychological risk and trialability is positive $(\beta=.31, \mathrm{t}=4.43)$. Additionally, time loss risk was only found to positively influence trialability $(\beta=.07, t=2.17)$. Finally, performance risk was only found to have positive_influence on relative advantage $(\beta=.08, t=2.47)$.

\section{3) Spanish Respondents}

For Spanish respondents, psychological risk was found to negatively influence relative advantage ( $\beta=-$ $.33, \mathrm{t}=-2.01)$, complexity $(\beta=-.46, \mathrm{t}=-3.17)$, but positively influence trialability $(\beta=.33, \mathrm{t}=2.17)$. However, 
time loss risk was found to have no significant relationship with relative advantage, complexity and trialability. Performance risk was only found to have positive_influence on trialability $(\beta=.22, \mathrm{t}=2.04)$.

\section{Summary of Hypotheses Test}

The research model of this study produced good model fitting indexes for Korean, U.S. and Spanish data. But there are some differences of the influence of perceived risk on perceived product attributes for smart clothing.

First, the influences of psychological risk among Korea, U.S. and Spain are same. Psychological risk has negative effect on relative advantage and complexity, but has positive effect on trialability.

Second, time loss risk was found to have nothing to do with relative advantage. But for Korean respondents, it was found to negatively influence complexity, but positively influence trialability. For U.S. respondents, the influence of time loss risk only was found to have positively relationship with trialability. For Spanish respondents, time loss risk was found to have no significant relationship with consumers' perceived product attributes.

Third, the influences of performance risk for different consumers are different. For Korean consumers, performance risk positively affects relative advantage and complexity, but does not affect trialability. For U.S. respondents, performance risk only can positively affect relative advantage. But for Spanish respondents, it only can positively affect trialability.

\section{Conclusions and Implications}

\section{Conclusions}

This paper is to examine the relationships between perceived risk and perceived attributes for adopting smart clothing and compare the differences among Korean, Spanish and U.S. cultural groups. For perceived risk, three dimensions were measured, which are psychological risk, time loss risk and performance risk. For perceived attributes, relative advantage, complexity and trialability were measured. A theoretical construct were built to measure the relationship among the six dimensions. Based on the SEM (Structural Equation Model), the findings are concluded as follow:

First, psychological risk was found to have significantly negative influences on relative advantage and complexity, and positive influence on trialability in all the three counties. For all the consumers, when the nervousness arises from the anticipated post-purchase emotions such as frustration, their perceived advantage and complexity of smart clothing will be lower. On some levels, more information about the innovative products will help consumers to reduce psychological anxiety. But on some other levels, the effect of information is negative. A deluge of information about latest products in the consumer electronic market, a certain assurance about the performance and the user-friendly attributes of products, are likely to put consumer relatively at ease in terms of psychological anxiety (Hirunyawipada \& Paswan, 2006).

Second, for all the consumers, time loss risk was not found to have significant relationship with relative advantage. Only for Korean consumers, time loss risk was found to have negative relationship with complexity, and for Korean and U.S. consumers, time loss risk was found to have positive relationship with trialability. For U.S. and Korean consumers, the interests for new technology and innovative products make them be willing to pay more time on learning, analyzing and trying the new products. And also, given the level of user friendliness in today's high tech gadgets, one could argue that most of the consumers perceived time loss risk may not be negatively influence consumers' perceived attributes for smart clothing.

Third, performance risk was found to have positive influence on relative advantage for U.S. and Korean consumers. Only for Korean consumers, performance risk has positive effect on complexity and only for Spanish consumers, performance risk has positive influence on trialability. For Korean and American consumers, high level of performance risk can cause high level of relative advantage. More probabilities of function failure can be concerned as more relative advantage. For pursuing the latest trend, some con- 
sumers may be stimulated by the innovative products. In today, because of the mass information sources, these concerns have been mitigated by consumers' expertise and interest. People who want to try smart clothing may already possess high level of knowledge and they want to try innovative products, especially Spanish consumers.

Perceived risk is domain-specific multi-dimensions factor having significant impacts on consumers' adoption, particularly the tendency to acquire new information (Hirunyawipada \& Paswan, 2006). Therefore, marketers need to consider not only functional feature of smart clothing, but also perceived psychological, time loss and performance risk which could influence consumers' perceived attributes for smart clothing. Appropriate information source will help consumers to reduce psychological risk and time loss risk in order to increase consumers' perceived attributes for smart clothing.

\section{Implications and Limitation}

The obtained results can be useful in order to guide the management of smart clothing. First, marketers should understand that different countries have a lot of differences when consumers accept a new technology product such as smart clothing. Among these three countries, smart clothing will be the easiest to be accepted by Korean consumers, this partly because Koran is considered as a new technology-based country by the world. Second, different consumers are influenced by different elements of innovativeness differently. To market new products successfully, marketers should realize the impact of cognitive, sensory and domain-specific innovativeness on innovation adoption (Hirunyawipada \& Paswan, 2006). Third, marketer should try their best to avoid different kinds of risks for different consumers and satisfy their different needs. For reducing the negative influences of perceived risk, marketers can use different communication ways (such as advertising, promotion etc.) to educate consumers and let them know the advantages of the new innovative products in order to increase their value.

However, some limitations also exist in this study. First, the data are collected from limited generation in limited locations. Second, the unequal data set may cause some problems in the results. Especially the small sample of Spain consumers may not reflect the true attitude of Spanish about smart clothing. The limited respondents in Spain and undone discriminant validity test also cause the validity and reliability problem which should be solved in the future research. Third, more than half of respondents are unaware of smart clothing. They respond it based on the descriptions of smart clothing which we provide in the questionnaire without actual experience. It is necessary to replicate this study based on the buyers who develop attitudes toward smart clothing and intention to repurchase. Forth, personal characteristics also should be considered in the future research.

\section{References}

Anderson, J. C., \& Gerbing, D. W. (1988). Structural equation modeling in practice: A review and recommended two-step approach. Psychological Bulletin, 103, 411-423.

Ariyatum, B., \& Holland, R. (2003). A strategic approach to new product development in smart clothing. Journal of the Asian Design International conference, 1, 70.

Bauer, R. A. (1960). Consumer behavior as risk taking. Proceedings of the Educators Conference, American Marketing Association, 389-398.

Black, N. J., Lockett, A., Winklhofer, H., \& Ennew, C. (2001). The adoption of internet financial services: A qualitative study. International Journal of Retail \& Distribution Management, 29(8), 390-398.

Bollen, K. A. (1989). Structural equations with latent variables. New York: John Wiley \& Sons.

Chen, R., \& He, F. (2003). Examination of brand knowledge, perceived risk and consumers' intention to adopt an online retailer. TQM \& Business Excellence, 14(6), 657-693.

Chung, K. H., \& Oh, J. S. (2001). Testing the SERVQUAL scale and perceived risk in internet. Journal of Global Academy of Marketing Science, 11, 1-21.

Conchar, M. P., Zinkhan, G. M., Peters, C., \& Olavarrieta, S. (2004). An integrated framework for the conceptualization of consumers' perceived-risk processing. Journal of the Academy of Marketing Science, 32(4), 418-436.

Cox, D. F. (1967). Risk handling in consumer behavior: An intensive study of two cases. In D. F. Cox (Ed.), Risk taking and information handling in consumer behavior (pp. 34-81). Boston: Harvard University Press.

Forsythe, S. M., \& Shi, B. (2003). Consumer patronage and risk perception in internet shopping. Journal of Busi- 
ness Research, 56(11), 867-875.

Hamilton, G. (2007). Product attributes and data feed marketing. Mercent.com. Retrieved May 1, 2007, from http://blog.mercent.com/posts/product_attributes/.

Hirunyawipada, T., \& Paswan, A. K. (2006). Consumer innovativeness and perceived risk: Implications for high technology product adoption. Journal of Consumer Marketing, 23(4), 182-198.

Holak, S. L., \& Lehmann, D. R. (1990). Purchase intention and the dimensions of innovation: An exploratory model. Journal of Product Innovation Management, 7, 59-73.

Huh, K. (2004). The effect of perceived risks on the consumer satisfaction in the use of cellular phone. Journal of Global Academy of Marketing Science, 11, 1-24.

Kim, J., \& Shin, Y. (2000). Factors influencing the consumers' perceived risks and purchase intention in the cyber shopping mall. Journal of Global Academy of Marketing Science, 6, 1-21.

Ko, E., Sung, H., \& Yoon, H. (2008). The effect of attributes of innovation and perceived risk on product attitude and intention to adopt smart wear. Journal of Global Academy of Marketing Science, 18(2), 89-112.

Lancaster, K. J. (1966). A new approach to consumer theory. Journal of Political Economy, 74(2), 132-158.

Lattin, J. M., Carroll, J. D., \& Green, P. E. (2003). Analyzing multivariate data. London: Thomson.

Littrell, M. A., \& Miller, N. J. (2001). Marketing across cultures: Consumers perceptions of product complexity, familiarity, and compatibility. Journal of Global Marketing, 15(1), 67-86.

Mann, S. (1997). Smart clothing: The wearable computer and wearCam. Personal and Ubiquitous Computing, 1(4), 218-224.

Marzano, S. (2000). The quest for power, comfort and freedom. In S. Marzano, J. Green, C. Heerden, \& J. Mama (Eds.), New nomads: An exploration of wearable electronics by philips (pp. 4-9). Rotterdam: 010 Publishers.

Mieres, C. G., Martin, A. M. D., \& Gutierrez, J. A. T. (2006). Influence of perceived risk on store brand proneness. International Journal of Retail \& Distribution Management, 34(10), 761-772.

Mitchell, V. W., Favies, F., Moutinho, L., \& Vassos, V. (1999). Using neural networks to understand service risk in the holiday product. Journal of Business Research, 46(2),
167-180

Mitchell, V. W., \& Harris, G. (2005). The importance of consumers' perceived risk in retail strategy. European Journal of Marketing, 39(7/8), 821-837.

Mowen, J. C., \& Minor, M. S. (2001). Consumer behavior: A framework. Englewood Cliffs: Prentice-Hall.

Ostund, L. E. (1974). Perceived innovation attributes as predictors of innovativeness. Journal of Consumer Research, 1(2), 23-29.

Ram, S., \& Sheth, J. N. (1989). Consumer resistance to innovations: The marketing problem and its solutions. Journal of Consumer Research, 6(2), 5-14.

Robert, N. S., \& Kjell, G. (1993). Perceived risk: Further considerations for the marketing discipline. European Journal of Marketing, 27(3), 39-50.

Rogers, E. M. (1983). The diffusion of innovations. New York: Free Press.

Rogers, E. M. (1995). Diffusion of innovations (5th ed.). New York: Free Press.

Shin, B. S., \& Park, J. Y. (2006). The effect of the consumer's perceived risk on level of information search. Journal of Global Academy of Marketing Science, 16(3), 143-167.

Sung, H., \& Jeon, Y. (2005). A study on Korean golfers' sun protective behavior and their intention to buy UV-protective clothing. Journal of the Korean Society of Clothing and Textiles, 29(1), 189-197.

Sung, H., \& Slocum, A. (2004). Golfer's intention to adopt UV specialize clothing as innovation based on Rogers theory. Journal of the Korean Society of Clothing and Textiles, 28(12), 1554-1561.

Taylor, J. (1974). The role of risk in consumer behavior. Journal of Marketing, 39, 54-60.

Textile \& Fashion Korea (2007). Smart clothes: A new challenge for the textile industry. Korea Federation of Textile Industries, March, 40-43.

Ziamou, P. (2002). Commercializing new technologies: Consumers' response to a new interface. Journal of Product Innovation Management, 19(5), 365-374.

Zinkhan, G. M., \& Karande, K. W. (1991). Cultural and gender differences in risk-taking behavior among American and Spanish decision-makers. Journal of Social Psychology, 131(5), 741-742. 


\section{요 약}

스마트 의류는 섬유 및 의류 산업, 전자 산업의 미래를 상징하는 것으로, 전자 기기들을 일생생활의 일 부로 만들기 위한 노력이 지속적으로 진행되고 있다. 기술 혁신이나 스마트 의류의 적용에 관한 선행연구 들이 진행되어 왔으나, 스마트 의류에 대한 인지나 태도에 대한 소비자 연구는 거의 없는 실정이다. 따라 서 이 연구에서는 소비자들이 스마트 의류 수용 속성에 대하여 지각된 위험이 어떠한 영향을 미치는지를 파악하고자 개념적 연구모형을 제시하였다. 또한 한국, 미국, 스페인간의 연구모형을 비교 분석하였다. 자료 분석을 위하여 $A \operatorname{mos} 7.0$ 을 이용하였으며 그 연구결과는 다음과 같다. 첫째, 한국, 미국 스페인 모두 에서 심리적 위험이 영향을 미치는 것으로 나타났다. 심리적 위험은 상대적 이점과 복잡성에 부정적인 영 향을 미쳤으나, 사용용이성에는 긍정적인 영향을 미쳤다. 둘째, 손실 위험은 상대적 이점에 유의한 영향 을 미치지 않는 것으로 나타났다. 하지만 손실 위험은 한국 소비자들의 복잡성에 부정적인 영향을 미치는 것으로 나타났으며, 한국과 미국 소비자들의 사용용이성에는 긍정적인 영향을 미쳤다. 셋째, 성과 위험의 영향은 국가별 소비자에 따라 다른 것으로 나타났다. 연구결과를 바탕으로 스마트 의류 관련 마케팅 전략 에 필요한 정보와 시사점을 제공하였다. 